\title{
THE DETERMINATION OF SERUM ACID AND ALKALINE PHOSPHATASE ACTIVITY WITH 4-AMINOANTIPYRINE (A.A.P.)
}

\author{
BY \\ M. E. A. POWELL AND M. J. H. SMITH \\ From the Department of Chemical Pathology, King's College Hospital Medical School, London
}

(RECEIVED FOR PUBLICATION DECEMBER 8, 1953)

Phenolic compounds give red or purple colours with 4-aminoantipyrine (A.A.P.) in the presence of alkaline oxidizing agents (Emerson, 1943). The amino group of the A.A.P. condenses with the phenol to give a substance which is oxidized to a coloured quinone.<smiles>CCCCCn1c(=O)n(C)n(C)c1=O</smiles>

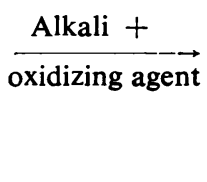

Gottlieb and Marsh (1946), using alkaine ferricyanide as the oxidant, devised a method for the estimation of certain phenolic fungicides with A.A.P. The procedure was modified by Grifols (1951) for the determination of phenol in the measurement of alkaline phosphatase activity in body fluids. This author made a careful study of the factors which control the development of the colour and his results showed good correlation with those obtained by the method of King (1951). Advantages claimed for the method were that the reagent did not react with proteins, thus obviating their precipitation during the estimation, and also the colour development was comparatively rapid. The use of A.A.P. as a reagent for phenol appeared to be of potential value especially if its use could be extended to the estimation of serum acid phosphatase activity. Considerable modification of the original Grifols procedure was found to be necessary in order to measure both alkaline and acid phosphatase activity in blood. The use of calibration curves, the stability of the colour, and the effect of the presence of serum on the colour development were also investigated. Results obtained with the proposed methods in a number of normal and pathological sera were compared with those obtained with King's methods.

\section{Experimental}

Reagents.-4-Aminoantipyrine hydrochloride (Hopkin \& Williams, Ltd.) was used without further purification. Potassium ferricyanide was of AR standard. The sodium carbonate/bicarbonate buffer, citric acid/sodium citrate buffer, and diphenyl phosphate substrate solution were prepared according to the directions of King (1951).

Standard phenol solutions were prepared by diluting a solution containing $1 \mathrm{~g}$. of pure crystalline phenol in 1 litre of water. The phenol content of this latter solution was estimated with N/10 bromine (British Pharmacopoeia, 1953).

The Estimation of Acid Phosphatase Activity.In acid solutions, oxidizing agents convert A.A.P. to the deeply coloured "antipyrine red" (Emerson, 1938) so that A.A.P. and ferricyanide cannot be used to estimate phenol produced after incubation of diphenyl phosphate substrate and serum in an acid buffer at $p H$ 4.9. In the original method of Grifols for alkaline phosphatase the $p \mathrm{H}$ of the final mixture after the addition of $\mathrm{M}-10$ carbonate was 10.2 . The corresponding mixture of serum and substrate after incubation with a citric acid buffer in the acid phosphatase method was at $p \mathrm{H} 4.9$, and $1 \mathrm{ml}$. of $22.5 \%$ w/v aqueous $\mathrm{Na}_{2} \mathrm{CO}_{3}$ was found to be necessary to produce a final $p \mathrm{H}$ of 10.2. Table I shows the results obtained from a series of phenol solutions of concentrations ranging from 10 to $100 \mu \mathrm{g} . / \mathrm{ml}$. which were estimated by the following two procedures; the concentrations of A.A.P. and ferricyanide employed were those used by Grifols (1951).

\begin{tabular}{|c|c|}
\hline Method A & Method B \\
\hline $\begin{array}{l}2 \text { ml. phenol solution } \\
2 \text { alkaline buffer } \\
1 " \text { M-10 sodium carbonate } \\
1 " \text { 0.06\% A.A.P. } \\
1 " \text { o.24\% potassium ferri- } \\
\text { cyanide }\end{array}$ & $\begin{array}{l}2 \text { ml. phenol solution } \\
2 \% \text { acid buffer } \\
1 \% 22 \cdot 5 \% \text { sodium carbonate } \\
1 \% 0.06 \% \text { A.A.P. } \\
1 \% 0.24 \% \text { potassium ferri- } \\
\text { cyanide }\end{array}$ \\
\hline
\end{tabular}


TABLE I

COMPARISON OF OPTICAL DENSITIES USING METHODS A AND B

\begin{tabular}{c|c|c}
\hline $\begin{array}{c}\text { Phenol } \\
(\mu \mathrm{g} . / \mathrm{ml} .)\end{array}$ & Method A & Method B \\
\hline 10 & 0.090 & 0.060 \\
15 & 0.135 & 0.095 \\
20 & 0.180 & 0.125 \\
25 & 0.220 & 0.160 \\
30 & 0.265 & 0.185 \\
40 & 0.330 & 0.230 \\
50 & 0.390 & 0.245 \\
75 & 0.520 & 0.370 \\
100 & 0.660 & 0.455 \\
\hline
\end{tabular}

The mixtures were allowed to stand at room temperature for 15 minutes and the optical densities measured in $\frac{1}{2} \mathrm{~cm}$. cells in the Spekker absorptiometer using Ilford spectrum green filters No. 604 .

The results show that, although the $p \mathrm{H}$ of the mixtures after the addition of the carbonate solutions were identical, the optical densities in method B were approximately $30 \%$ lower than those using method A. It therefore appeared that the citrate present in the acid buffer interfered in some way with the production of the colour. A similar result was observed when acid buffers containing acetate or phthalate were used. Gottlieb and Marsh (1946) reported that attempts to utilize alkaline borate and glycine buffer mixtures in their work on the estimation of phenolic fungicides were not successful because the colour development was decreased.

On the empirical reasoning that the buffer ions in some way reacted with the reagents, it was decided to increase the concentrations of A.A.P. and ferricyanide in methods A and B described above. Table II summarizes this series of experiments, a $40 \mu \mathrm{g} . / \mathrm{ml}$. phenol solution being used throughout.

TABLE II

EFFECT OF INCREASING REAGENT CONCENTRATIONS

\begin{tabular}{c|c|c|c}
\hline \multirow{2}{*}{$\begin{array}{c}\text { A A.P. } \\
\text { (g. } 100 \mathrm{ml} \text { ) }\end{array}$} & $\begin{array}{c}\text { Ferricyanide } \\
\text { (g. } 100 \mathrm{ml} .)\end{array}$ & \multicolumn{2}{|c}{ Optical Density } \\
\cline { 3 - 4 } & & Method A & Method B \\
\hline 0.06 & 0.24 & 0.320 & 0.230 \\
0.12 & 0.48 & 0.460 & 0.235 \\
0.24 & 0.96 & 0.580 & 0.244 \\
0.50 & 1.0 & 0.631 & 0.383 \\
1.0 & 2.0 & 0.647 & 0.497 \\
1.0 & 4.0 & 0.650 & 0.559 \\
1.5 & 4.0 & 0.625 & 0.563 \\
1.5 & 6.0 & 0.627 & 0.560 \\
2.0 & 2.0 & 0.490 & 0.354 \\
2.0 & 6.0 & \multicolumn{2}{|c|}{ Turbid solutions } \\
\hline
\end{tabular}

The results show that there was some improvement in the optical densities obtained with increasing amounts of reagents. However, the agreement with the results obtained with the two methods was still unsatisfactory. One point which emerged from the work was that the original Grifols concentrations did not give full colour development and were inadequate for amounts of phenol corresponding to phosphatase values above 100 units. If excess phenol were present it acted as a reducing agent converting the red quinone to a colourless leuco compound. Fig. 1 illus trates this effect using increasing amounts of phenol and $0.06_{\circ}^{\circ}$ A.A.P. and $0.24 \%$ ferricyanide.

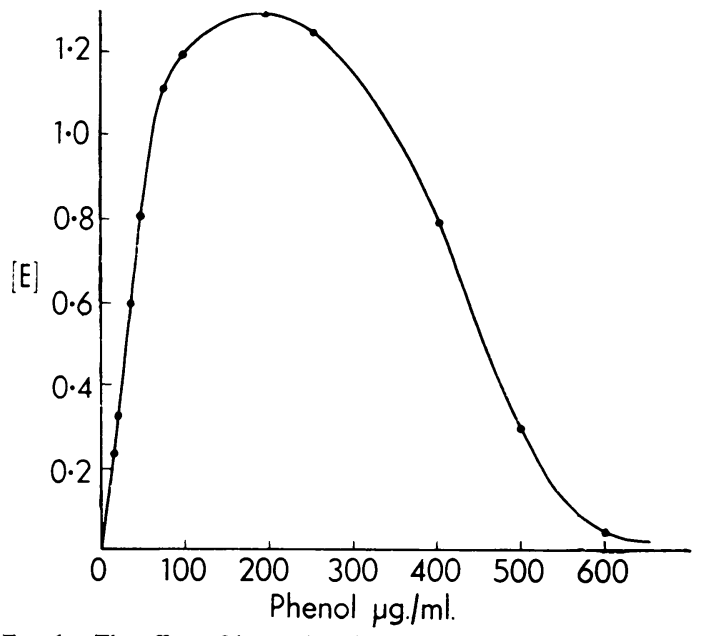

Fig. 1.-The effect of increasing the amount of phenol using $0.06 \%$ A.A.P. and $0.24 \%$ ferricyanide.

The only difference between the substances used in the alkaline and acid buffers and their subsequent treatment apart from the citric acid and citrate in the acid buffer was sodium bicarbonate. It was therefore decided to investigate the use of various carbonate/bicarbonate mixtures instead of $22.5^{\circ} \%$ carbonate in method B. 4-Aminoantipyrine, $1.5 \mathrm{~g} . / 100 \mathrm{ml}$. and $4 \mathrm{~g} . / 100 \mathrm{ml}$. ferricyanide were used because the results in Table II indicated that these were the optimum concentrations of the reagents. Table III summarizes the results of these experiments using a $40 \mu \mathrm{g} . / \mathrm{ml}$. phenol solution.

The results indicated that both the concentrations and ratio of the sodium carbonate and sodium bicarbonate in the mixture were important factors. Although the addition of $1 \mathrm{ml}$. of a solution containing $7.5 \mathrm{~g} . / 100 \mathrm{ml}$. of sodium carbonate and sodium bicarbonate gave optimum results, the addition of $2 \mathrm{ml}$. of the $4 \mathrm{~g} . / 100 \mathrm{ml}$. concentrations was preferred because the former mixture deposited crystals on standing at room temperature.

TABLE III

EFFECT OF USING SODIUM CARBONATE SODIUM BICAR BONATE MIXTURES IN METHOD $B^{*}$

\begin{tabular}{c|c|c|c}
\hline \multicolumn{2}{c|}{$\begin{array}{c}\text { Composition of Mixture } \\
\text { (g. 100 ml.) }\end{array}$} & \multicolumn{2}{|c}{ Optical Density } \\
\cline { 1 - 2 } $\mathrm{Na}_{2} \mathrm{CO}_{3}$ & $\mathrm{NaHCO}_{3}$ & Method A & Method B* \\
\hline 22.5 & 0 & 0.625 & 0.563 \\
10 & 2.5 & 0.625 & 0.575 \\
5 & 2.5 & 0.630 & 0.580 \\
5 & 5 & 0.625 & 0.600 \\
7.5 & 7.5 & 0.620 & 0.620 \\
$44^{\dagger}$ & 4 & 0.545 & 0.550
\end{tabular}

* The concentrations of A.A.P. and ferricyanide were $1.5 \%$ and 4.0\% respectively.

mixture added in Method B and $2 \mathrm{ml}$. of M-10 sodium carbonate added in Method A. 
Development and Stability of Final Colour.Fig. 2 illustrates the increase in colour intensity with time of a phenol solution estimated by both acid and alkaline procedures. The colour with the alkaline method is fully developed in five minutes whereas with the acid method 15 minutes is necessary. The final colour is stable for at least two hours, but has diminished to approximately $90 \%$ of its maximum intensity in six hours.

Final Method.-The suggested procedures for acid and alkaline phosphatase estimations in serum are as follows:

\begin{tabular}{|c|c|}
\hline Alkaline Phosphatase & Acid Phosphatase \\
\hline $\begin{array}{l}\text { Carbonate bicarbonate buffer, } \\
2.0 \mathrm{ml} \text {. } \\
\text { Diphenyl phosphate solution, } \\
2.0 \mathrm{ml} \text {. } \\
\text { Serum, } 0.2 \mathrm{ml} \text {. } \\
\text { Incubate at } 37^{\circ} \mathrm{C} \text {. for } 15 \mathrm{~min} . \text {, } \\
\text { then add } \\
\text { M-10 carbonate, } 20 \mathrm{ml} \text {. } \\
1.5 \% \text { A.A.P., } 1.0 \mathrm{ml} . \\
4 \% \text { ferricyanide, } 1.0 \mathrm{ml} \text {. }\end{array}$ & $\begin{array}{l}\text { Citrate buffer, } 2.0 \mathrm{ml} \text {. } \\
\text { Diphenyl phosphate solution, } \\
2.0 \mathrm{ml} \text {. } \\
\text { Serum, } 0.2 \mathrm{ml} \text {. } \\
\text { Incubate at } 37^{\circ} \mathrm{C} \text {. for } 60 \mathrm{~min} . \text {, } \\
\text { then add } \\
4 \% \text { carbonate }\{\text { solution } \\
4 \% \text { bicarbonate } 2.0 \mathrm{ml} \text {. } \\
1.5 \% \text { A.A.P., } 1.0 \mathrm{ml} \text {. } \\
4 \% \text { ferricyanide, } 1.0 \mathrm{ml} \text {. }\end{array}$ \\
\hline
\end{tabular}

The alkaline phosphatase estimations are allowed to stand at room temperature for five minutes, and the acid tubes for 15 minutes (cf. Fig. 2). The optical densities are measured in a Hilger Spekker absorptiometer using Ilford spectrum green filters No. 604. The optical densities are read against control solutions prepared as above except that the serum is added after the incubation.

Calibration Curves.-Calibration curves as shown in Fig. 3 may be constructed by substituting $2 \mathrm{ml}$. of phenol solution varying in concentration from 5 to $100 \mu \mathrm{g} . / \mathrm{ml}$. for the substrate solution. In the present method one phosphatase unit is equivalent to that of King and Armstrong, i.e., $2 \mu \mathrm{g}$. of phenol liberated

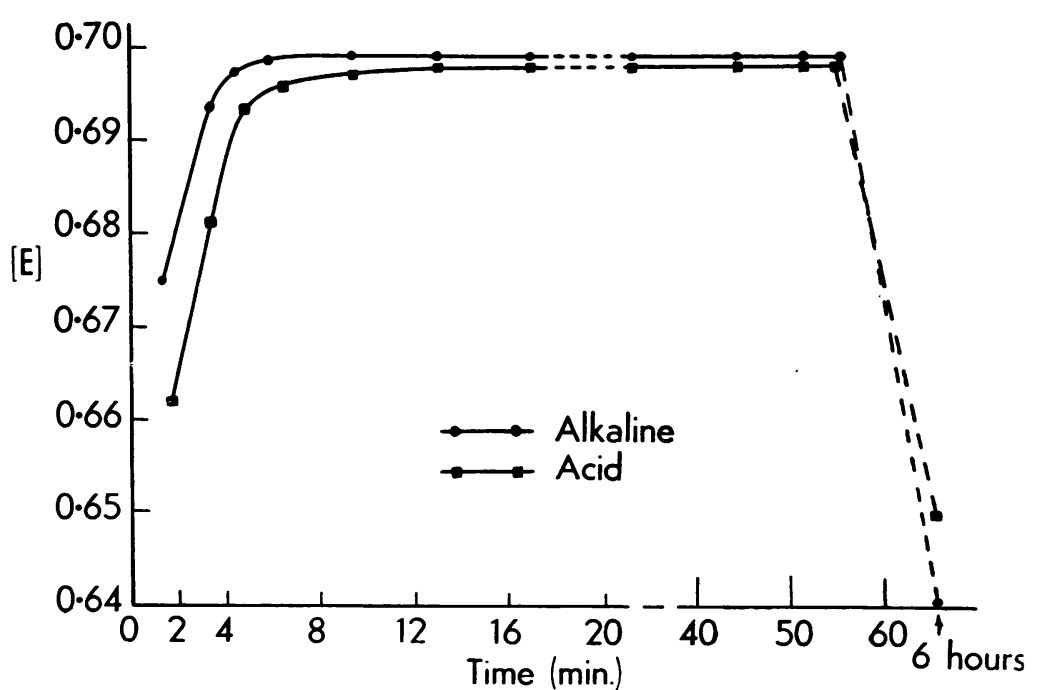

FIG. 2.-Rate of development and fading of final colour. from the substrate under the various incubation conditions; in the standard solutions used for the preparation of the calibration curves $1 \mu \mathrm{g} . / \mathrm{ml}$. of phenol equals 1 phosphatase unit. Each solution used for the calibration curves had $0.2 \mathrm{ml}$. serum added because the presence of serum decreases the optical density by 5 to $10 \%$ as shown in Table IV.

TABLE IV

\section{EFFECT OF SERUM ON COLOUR DEVELOPMENT}

\begin{tabular}{c|c|c|c|c}
\hline & \multicolumn{4}{|c}{ Optical Densities } \\
\cline { 2 - 4 } $\begin{array}{c}\text { Phenol } \\
\text { Solution* }\end{array}$ & Wg./ml.) & Water & \multicolumn{2}{|c}{ Amount of Serum Added } \\
\cline { 2 - 4 } & & $0.1 \mathrm{ml}$. & $0.2 \mathrm{ml}$. & $0.4 \mathrm{ml}$. \\
\hline 10 & 0.148 & 0.140 & 0.135 & 0.130 \\
15 & 0.220 & 0.220 & 0.210 & 0.204 \\
20 & 0.298 & 0.289 & 0.291 & 0.273 \\
30 & 0.458 & 0.442 & 0.420 & 0.408 \\
40 & 0.592 & 0.565 & 0.558 & 0.534 \\
50 & 0.731 & 0.690 & 0.683 & 0.670 \\
\hline
\end{tabular}

* The final volume of each solution was identical, the serum having been substituted for an equal volume of water.

Comparison of Results with those Obtained by King's Methods. - The results obtained with both the above methods and the methods of King (1951) for acid and alkaline phosphatase activities in a number of blood specimens are shown in Tables $\mathrm{V}$ and VI.

\section{Conclusion}

While the original method of Grifols was found to be adequate for the determination of alkaline phosphatase activity it could not be applied directly to the measurement of serum acid phosphatase activity because the anions present in the acid buffer solution interfered with the colour production. The procedure was modified by the addition of a bicarbonate/carbonate solution after the incubation and the use of much greater concentrations of A.A.P. and ferricyanide so that this interference due to the buffer anions was overcome. It has been possible to devise methods for the estimation of both types of phosphatase activity in serum using the same calibration curves. The presence of serum tends to decrease the colour intensity, and it is recommended that the calibration curves should be constructed with $0.2 \mathrm{ml}$. of serum in each estimation. This effect of serum was not studied by Grifols, who merely stated that A.A.P. 


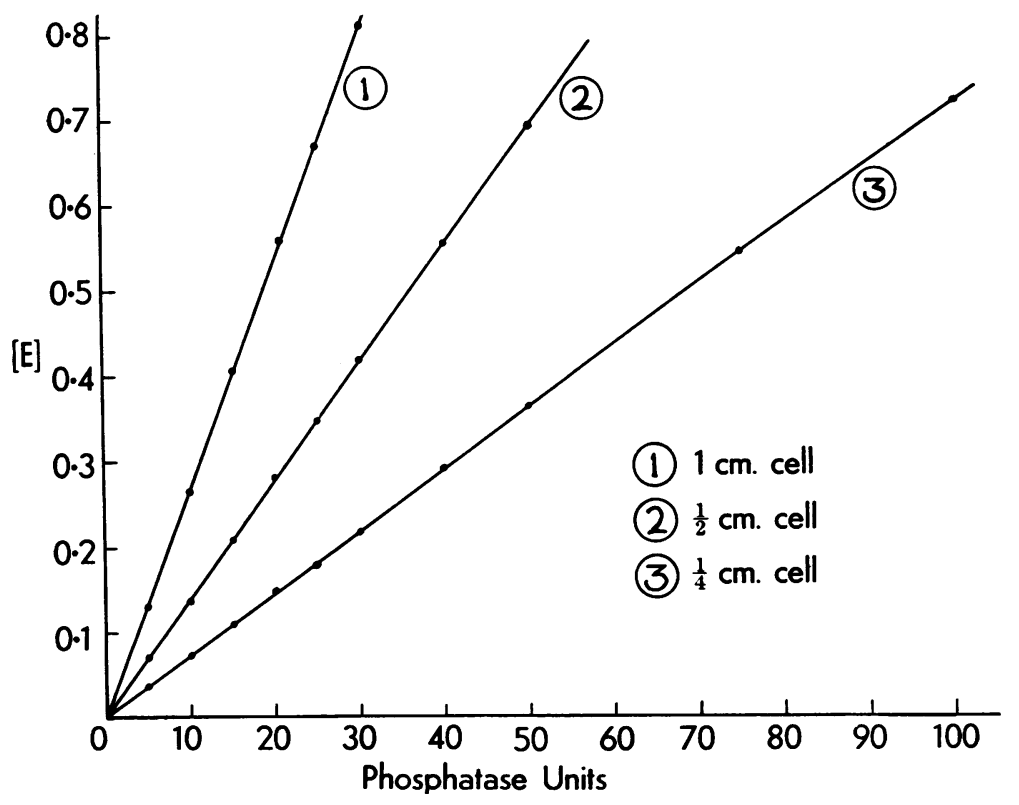

Fig. 3.-Calibration curves for both acid and alkaline phosphatase estimations using various sizes of optical cells.

did not react with plasma proteins.

The results obtained with the present methods in a number of sera from normal persons and patients suffering from jaundice and carcinoma of the prostate have been compared with the results obtained by the method of King (1951). A good agreement between the results was observed as is shown in Tables V and VI. In our opinion the present methods have several advantages over those of King, notably in the speed and simplicity of manipulation. Serum proteins do not require precipitation, thus eliminating centrifugation and removal of a supernatant solution, and the final colour development does not involve an incubation. An estimation of serum alkaline phosphatase activity can be made in about 25 minutes, and the final colour is stable for several hours at room temperature.

\section{Summary}

The use of 4-aminoantipyrine (A.A.P.) for the measurement of phenol in the final stage of the estimation of serum phosphatase activity has been studied.

Methods have been devised for the determination of both serum acid and alkaline phosphatase activity using the same calibration curves.

Results with these methods have been compared with those obtained using the methods of King.

We wish to thank Miss E. Quilley for technical assistance and the Board of Governors of King's College Hospital, London, for a grant towards the cost of the work.

\section{REFERENCES}

Emerson, E. [Eisenstaedt, E.] (1938). J. org. Chem., 3, 153. - (1943). Ibid., 8, 417.

Gottlieb, S., and Marsh, P. B. (1946). Industr. Engng Chem., Anal. Edit., 18, 16.

Grifols, J. A. (1951). Brit. med. J., 2, 295

King, E. J. (1951). Micro-Analysis in Medical Biochemistry, 2nd ed. Churchill, London. 